\title{
HUBUNGAN ANTARA RELIGIUSITAS DAN STRES DENGAN PSYCHOLOGICAL WELL BEING PADA REMAJA PONDOK PESANTREN
}

\author{
Rahmawati Dwi Anggraeni \\ Program Studi Psikologi Universitas Negeri Surabaya
}

\begin{abstract}
Abstrak: Penelitian ini bertujuan untuk menguji: (1) hubungan antara religiusitas dan psychological well being remaja Pondok Pesantren Assalafi Al-Fithrah, Surabaya, (2) hubungan antara stres dan psychological well being remaja Pondok Pesantren Assalafi Al-Fithrah, Surabaya, dan (3) hubungan antara religiusitas dan stres dengan psychological well being pada remaja Pondok Pesantren Assalafi AlFithrah, Surabaya. Penelitian ini mengunakan metode kuantitatif korelasional. Terdapat tiga skala yang digunakan dalam penelitian ini, yakni skala religiusitas, skala stres, dan skala psychological well being. Peneliti menggunakan sebanyak 77 santri Pondok Pesantren Assalafi Al-Fithrah, Surabaya sebagai sampel penelitian yang dipilih dengan menggunakan teknik random sampling. Teknik analisis data yang digunakan dalam penelitian ini ialah uji analisis regresi linier berganda. Hasil penelitian ini menunjukkan bahwa: (1) religiusitas memiliki hubungan yang signifikan dengan psychological well being dengan arah hubungan yang positif yang dapat dilihat dari nilai signifikansi sebesar 0,000 dan koefisien regresi 0,559 . (2) stres memiliki hubungan siginifikan dengan psychological well being dengan arah hubungan yang negatif yang dapat dilihat dari nilai signifikansi sebesar 0,000 dan koefisien regresi -0,460. (3) nilai $\mathrm{R}_{\text {square }}$ sebesar 0,593; artinya sebesar 59,3\% variasi pada psychological well being dipengaruhi oleh religiusitas dan stres, sisanya sebesar $40,7 \%$ disebabkan oleh variabel lain yang tidak diukur dalam penelitian ini. Hubungan antara religiusitas dan stres dengan psychological well being diketahui memiliki hubungan yang signifikan dengan nilai signifikansi sebesar 0,000 .
\end{abstract}

Kata kunci : Religiusitas, stres, psychological well being, dan remaja.

\begin{abstract}
The purposes of this study is to reveal : (1) the correlation between religiousity and psychological well being of the adolescent in Pondok Pesantren Assalafi Al Fihtrah, Surabaya, (2) the correlation between stress and psychological well being of the adolescent in Pondok Pesantren Assalafi Al fithrah, Surabaya, and (3) the correlation of religiousity, stress, and psychological well being of the adolescent in Pondok Pesantren Assalafi Al fithrah. Surabaya. The method of this study is a correlational quantitative by using three scales which are; religiousity scale, stress scale, and psychological well being scale. Researcher chose 77 students in Pondok Pesantren Assalafi Al Fithrah, Surabay and they were selected using random sampling technique. Data analysis technique used in this study was multiple linear reggresion analysis test. The result of this study showed that : (1) religiousity has significant correlation with psychological well being, with positive direction of correlation which can be seen from the level of significance which was 0,000 and the reggresion coefficients was 0,559 (2) stress has significant correlation with psychological well being in the negative direction of correlation which can be seen from the level of significance of 0.000 and the regression coefficient of -0,460; and (3) the $R_{\text {square }}$ value is 0,593 , which is mean that the $59,3 \%$ of variation in psychological well being is influenced by the religiousity and stres, and the rest of $40,7 \%$ is cause by another variable which is not measured in this research. The correlation between religiousity and stress with psychological well being is known having a significant correlation with 0,000 of significance value.
\end{abstract}

Keywords: Religiousity, stress, psychological well being, adolescent.

Permasalahan mengenai remaja memang selalu menarik untuk dikaji, termasuk diantaranya remaja yang tinggal di pondok pesantren. Pondok pesantren merupakan lembaga pendidikan Islam tertua di Indonesia. Keberadaan pondok pesantren dimulai sejak agama Islam masuk. Salah satu pondok pesantren besar di wilayah utara kota Surabaya ialah Pondok Pesantren (Ponpes)
Assalafi Al-Fithrah. Di Ponpes tersebut terdapat dua jenis santri, yakni santri kalong dan santri mukim. Santri kalong ialah santri yang setiap selesai proses pendidikan di pesantren kembali ke rumah dan tidak menetap dalam pondok yang biasanya berasal dari lingkungan sekitar pesantren. Sedangkan, santri mukim ialah santri yang belajar dan menetap di asrama yang ada dalam Ponpes 
dan biasanya berasal dari daaerah yang jauh (Dhofier, dalam Muzammilah, 2008).

Para santri yang tinggal di Ponpes memiliki peluang untuk hidup dengan mandiri. Selain tinggal jauh dari orang tua, kemandirian tersebut dapat pula terbentuk oleh adanya bagian atau bidang tugas yang diberikan pada mereka. Bidang tugas tersebut antara lain bagian kebersihan, pengairan, listrik, dan lain-lain. Bidang tugas kerja tersebut melatih para santri untuk dapat berbuat mandiri dan bertanggung jawab atas bidang kerja yang dilakukannya. Serta, dapat memupuk kerja sama dengan anggota pada bidang kerja yang dipilihnya. Kemandirian merupakan salah satu dimensi psychological wellbeing. Individu yang dapat hidup secara mandiri ialah individu yang memiliki psychological well being yang baik.

Ryff (1989) menyatakan bahwa hal penting dalam psychological well being seseorang adalah penerimaan terhadap diri sendiri, hubungan positif dengan orang lain, kemandirian atau otonomi, penguasaan lingkungan, mempunyai tujuan hidup dan makna hidup, serta mempunyai perasaan akan pertumbuhan dan perkembangan berkelanjutan. Ryff menegaskan bahwa seseorang yang jiwanya sejahtera apabila ia tidak sekedar bebas dari tekanan atau masalah mental lain. Individu dengan psychological well being yang baik ialah individu yang memiliki penilaian positif terhadap dirinya, mampu bertindak secara otonom, tidak mudah hanyut oleh pengaruh lingkungan, memiliki hubungan yang positif dengan orang lain, menyadari bahwa hidupnya bermakna dan bertujuan. Selain itu, individu tersebut dapat merasakan dirinya tetap berkembang dan bertumbuh, serta mampu menguasai lingkungannya (Ryff, 1989).

Selain kemandirian, tinggal di Ponpes juga dapat memupuk kerjasama. Kerja sama yang dilakukan santri dalam bidang kerjanya berkaitan dengan dimensi hubungan positif dengan orang lain dalam psychological wellbeing. Dimensi ini menyebutkan bahwa individu yang memiliki psychological well being yang baik, salah satunya dapat dinilai dari kemampuannya membentuk hubungan yang hangat dan positif dengan orang lain dan kemampuan dalam berinteraksi dengan orang lain. Berdasarkan hasil wawancara dengan Wakasek Madrasah Aliyah (mu'adalah) Ponpes Assalafi Al-Fithrah, diketahui bahwa beberapa santri merasakan adanya ketidaknyamanan. Kondisi ini terjadi ketika dalam salah satu materi, para santri junior harus berada satu kelas dengan santri senior (kakak angkatan). Dalam situasi tersebut, baik santri senior maupun junior merasa bahwa dirinya telah memiliki komunitas atau kelompok sendiri, sehingga apabila ada santri lain yang masuk dalam kelas tersebut mereka merasa tidak nyaman. Sebagai kakak angkatan (santri senior) mereka merasa sudah menguasai materi yang diajarkan, sehingga tidak ingin dicampur dengan adik kelas (junior) dalam materi yang sama. Selain itu, berdasarkan wawancara yang dilakukan dengan beberapa santri putra dan putri diketahui bahwa sebagian besar dari santri mampu berhubungan baik dengan orang lain yang satu kamar atau satu kelas saja.

Dimensi penguasaan lingkungan yang ada dalam psychological well being yang tampak pada remaja Ponpes Assalafi AlFithrah ialah kemampuan mereka dalam memimpin kelompok atau kelas. Sebagian besar santri yang pernah menjadi ketua kelompok ataupun ketua kelas menyatakan bahwa mereka lebih memilih menjadi anggota dibanding memimpin kelompok. Bagi mereka, memimpin kelompok memiliki kesulitan tersendiri, seperti merasa sungkan karena pada kelompok tersebut ada yang berusia lebih tua dari dirinya atau karena anggota yang ada sulit diatur. Namun, bagi mereka yang belum merasakan memimpin sebuah kelompok, memiliki keinginan untuk menjadi ketua kelompok. Bagi mereka, memimpin kelompok memiliki tantangan tersendiri bagi dirinya.

Memiliki tujuan hidup atau mampu memaknai hidup dengan baik merupakan 
salah satu dimensi yang ada dalam psychological well being. Berdasarkan hasil wawancara dengan beberapa santri Ponpes Assalafi Al-Fithrah diketahui bahwa mereka telah memiliki cita-cita untuk menjadi guru sebagai penyebar agama Islam ketika mereka keluar dari Ponpes. Adapula santri yang mencoba membangun link dengan temanteman yang berada di luar Pondok agar kelak dapat mendirikan sebuah lembaga yang dapat berguna untuk menyebarkan agama Islam.

Berdasarkan hasil wawancara yang dilakukan dengan beberapa santri Ponpes Assalafi Al-Fithrah, diketahui bahwa sebagian besar dari mereka menyatakan bahwa awal mula mereka masuk dan menjadi santri Ponpes adalah atas keinginan orang tua. Namun, setelah mendapat pandangan dan mengerti manfaat menjadi santri Ponpes mereka mulai menerima dan membiasakan diri dengan lingkungan Ponpes. Menurut Cloninger (dalam Garcia \& Siddqui, 2009) penerimaan diri merupakan langkah penting untuk menjadi bahagia. Apabila seorang individu ingin mampu menyesuaikan diri, merasa baik, dan menyelesaikan permasalahan hidupnya, orang tersebut harus menerima semua bagian yang berbeda dalam dirinya.

Lingkungan agamis dan religius yang dijalani remaja Ponpes Assalafi Al-Fithrah menuntut mereka agar mampu menyesuaikan dirinya dengan lingkungan tersebut. Mereka dididik untuk dapat mandiri, mampu mengendalikan berbagai situasi yang dihadapi, mampu menjalin hubungan dengan santri lain, menerima kondisi diri, memiliki tujuan hidup yang jelas, dan mampu mengembangkan potensi yang dimiliki. Halhal tersebut sesuai dengan aspek yang terdapat dalam psychological well being yang harus dimiliki untuk dapat mencapai psychological well being yang baik.

Berkaitan dengan usaha remaja Ponpes dalam mencapai psychological well being yang baik, diduga berkaitan dengan faktor religiusitas dan stres yang dihadapi para santri. Berdasarkan uraian tersebut diketahui bahwa lingkungan Ponpes, khususnya Ponpes Assalafi Al-Fithrah, memiliki lingkungan religius yang dapat menunjang kualitas religius para santrinya. Lingkungan religius tersebut terbentuk oleh adanya aktivitasaktivitas keagamaan yang dilakukan oleh seluruh penghuni Ponpes sepanjang hari.

Pada Ponpes Assalafi Al-Fithrah, peneliti memperoleh gambaran bahwa lingkungan Ponpes memiliki banyak kegiatan yang berhubungan dengan keagamaan. Kegiatan-kegiatan tersebut dilakukan oleh para santri semenjak pagi hingga malam hari. Sehingga, religiusitas yang dimiliki remaja Ponpes berasal dari kegiatan keagamaan yang mereka lakukan sepanjang hari tersebut. Berdasarkan hasil wawancara yang dilakukan dengan salah satu Wakasek Madrasah Aliyah (mu'adalah) Ponpes Assalafi Al-Fithrah, kegiatan yang dilakukan oleh santri antara lain shalat berjamaah, membaca Al-Qur'an bersama, musyawarah/belajar bersama, sekolah, dan lain-lain. Pernyataan tersebut diperkuat oleh beberapa santri mukim di Ponpes Assalafi Al-Fithrah, yang menyatakan bahwa rutinitas keagamaan tersebut dilakukan oleh seluruh santri baik putra maupun putri selama hampir dua puluh empat jam. Selain kegiatan-kegiatan yang bersifat ritualistik para santri juga dibiasakan untuk berperilaku agamis, seperti mengucapkan salam, hormat dan patuh kepada para kyai dan ustad/ustadzah, berpakaian rapi dan sopan, menaati peraturan yang ditetapkan Ponpes, dan lain-lain.

Rutinitas keagamaan tersebut ditunjang dengan bobot materi agama yang diterima santri selama menjalani proses pendidikan di sekolah yang ada di Ponpes. Berdasarkan hasil wawancara yang dilakukan dengan salah satu Wakasek Madrasah Aliyah (mu'adalah) Ponpes Assalafi Al-Fithrah, dalam kurikulum pendidikannya Ponpes menerapkan pendidikan agama dan umum. Persentase perbandingan pendidikan agama dan materi pelajaran umum yang diterapkan, yakni masing-masing sebesar $70 \%$ untuk 
pendidikan agama dan 30\% untuk pendidikan atau materi pelajaran umum. Dengan perbandingan tersebut, tentunya sebelum masuk dan terdaftar sebagai santri di lingkungan Ponpes Assalafi Al-Fithrah para calon santri harus mampu memenuhi persyaratan yang ditetapkan pihak Ponpes, seperti menghafal ayat Al-Qur'an, membaca Al-Qur'an dengan baik, dll. Sehingga, apabila calon santri tersebut belum mampu memenuhi syarat yang diberikan oleh pihak Ponpes, maka akan dimasukkan ke dalam sekolah persiapan atau yang disebut istidad selama lebih kurang satu tahun. Apabila dalam satu tahun tersebut calon santri dianggap mampu dan memenuhi persyaratan, maka ia dapat masuk dan dinyatakan sebagai santri.

Religiusitas yang dimiliki oleh setiap individu sepanjang rentang kehidupannya selalu berkembang dari masa ke masa, tidak terkecuali seorang remaja. Remaja adalah tahap yang sangat kritis dan penting dalam perkembangan manusia. Kebanyakan perubahan fisik, psikologis, dan sosial pada manusia terjadi selama periode ini. Periode remaja dapat dilihat sebagai masa yang memiliki perjuangan dan gejolak lebih dari masa kanak-kanak (Rathi \& Rastogi, 2007).

Berkaitan dengan jiwa remaja yang selalu bergejolak, keyakinan beragama remaja memiliki keunikan tersendiri. Religiusitas remaja berkembang dari masa anak-anak yang tidak memaknai nilai agama sebagai sesuatu yang penting, menjadi keinginan yang cukup besar untuk mengetahui masalah-masalah mengenai agama. Mereka mulai memperdalam pengetahuannya mengenai agama yang diyakininya. Menurut Hurlock (1990) remaja mulai memiliki minat pada agama dan menganggap agama berperan penting dalam kehidupan. Mereka beranggapan demikian karena mereka bukan lagi seorang anak-anak yang selalu dituntun oleh orang tuanya. Santrock (2003) menjelaskan bahwa remaja lebih memiliki ketertarikan pada agama dan keyakinan spiritual daripada anak-anak.
Sebelumnya remaja mengandalkan semuanya pada keyakinan orang tuanya. Ini tampak pada masa remaja akhir, individu menghadapi keputusan-keputusan pribadi, mulai mengevaluasi beberapa pertanyaan mengenai keyakinan dan kepentingan orang lain.

Holder et. al. (dalam Steinberg, 2005) dalam penelitiannya diketahui bahwa keyakinan remaja terhadap agama lebih berorientasi pada hal-hal spiritual dan pemahaman dibandingkan dengan ritual, praktik, dan ibadah yang kaku dalam kebiasaan-kebiasaan religius. Sebagai contoh, meskipun $87 \%$ dari remaja berdo'a dan $95 \%$ percaya kepada Tuhan, $60 \%$ dari keseluruhan remaja merasakan bahwa agama yang terorganisasi tidak berperan penting dalam kehidupan mereka.

Colbert, dkk (2009) menyebutkan bahwa usia berkorelasi positif dengan orientasi keagamaan secara intrinsik, begitu juga hubungan dengan orientasi keagamaan ekstrinsik dengan variabel demografis lainnya. Penemuan ini konsisten dengan penemuan Benjamin (dalam Colbert dkk, 2009) yang menyebutkan bahwa usia berhubungan dengan religiusitas secara signifikan. Semakin matang usia seseorang, maka keterlibatan pada hal-hal yang bersifat religius semakin meningkat. Dan dapat disimpulkan bahwa tingkat keterlibatan keagamaan yang lebih tinggi memiliki hubungan dengan kematangan dan usia.

Sepanjang rentang kehidupan, manusia selalu dihadapkan pada masalah-masalah tertentu. Masalah-masalah yang tidak mampu terselesaikan dengan baik akan dapat memunculkan sebuah stres. Stres bukanlah sesuatu yang mudah untuk didefinisikan. Remaja dapat memikirkan, mempertimbangkan, dan mengalami begitu banyak situasi sosial yang dapat membuat stres (Santrock, 2003). Chaplin (2009) mendefinisikan stres (kata benda) sebagai keadaan tertekan, baik secara fisik maupun psikologis. Stres pada masa remaja dapat didefinisikan sebagai suatu ancaman dan tantangan yang ditekankan 
lingkungan pada diri mereka.

Penyebab munculnya stres pada remaja mengalami peningkatan dibanding masamasa sebelumnya (Santrock, 2003). Sehingga, dapat dikatakan bahwa banyak faktor yang dapat menghasilkan stres dalam kehidupan remaja. Faktor-faktor tersebut dapat bersifat ekstrem atau hanya berupa kejadian sehari-hari. Kejadian ekstrem yang mampu memunculkan stres pada remaja, seperti kecelakaan kendaraan dan kematian seorang teman atau anggota keluarga. Sedangkan kejadian sehari-hari yang dapat memunculkan stres pada remaja, seperti tugas sekolah dan pekerjaan yang berlebihan, merasa frustasi dengan kondisi keluarga yang tidak menyenangkan, dan kondisi ekonomi yang kurang (Santrock, 2003).

Dalam penelitian yang dilakukan oleh Suryandari (2004) mengenai "Perbedaan Religiusitas Remaja ditinjau dari Coping Behavior", menunjukkan bahwa tidak ada perbedaan religiusitas remaja jika ditinjau berdasarkan coping behavior, namun terdapat variasi religiusitas remaja berdasarkan kategori coping behavior. Dengan begitu dapat dikatakan bahwa religiusitas memiliki peran bagi remaja dalam menghadapi permasalahan (stressor) yang dihadapinya.

Remaja yang tinggal dan belajar di Ponpes menjalani rutinitas kehidupan pesantren yang penuh dengan nuansa rohani dan akademis, yang dapat menunjang religiusitasnya. Pada masa remaja, penyebab munculnya stres meningkat dibanding masa sebelumnya. Permasalahan-permasalahan tersebut dapat berasal dari dalam maupun dari luar lingkungan Ponpes. Masalah-masalah yang tidak mampu terselesaikan dengan baik akan dapat memunculkan stres. Dengan kualitas religiusitas yang baik, akan berdampak bagi remaja dalam menghadapi setiap permasalahan dalam kehidupannya.

Individu dengan religiusitas yang tinggi dan stres yang rendah, diharapkan dapat mencapai psychological well being yang baik. Psychological well being yang baik dapat diperoleh dari sikap mandiri yang diajarkan oleh pihak Ponpes, bagaimana para santri dapat membina hubungan baik dengan santri yang lain, mampu mengembangkan potensi dalam dirinya, menerima kondisi dirinya, dan memiliki arah hidup yang jelas.

Berdasarkan uraian tersebut, maka permasalahan penelitian ini dapat dirumuskan sebagai berikut: "Apakah terdapat hubungan antara religiusitas dan tingkat stress dengan psychological well being pada remaja pondok pesantren?"

\section{METODE}

Penelitian ini menggunakan metode kuantitatif korelasional. Metode korelasional dimaksud untuk mencari hubungan diantara variabel-variabel yang diteliti dan bertujuan untuk meneliti sejauh mana variabel pada satu faktor berkaitan dengan variasi pada faktor lainnya (Hasan, 2002).

\section{Sampel}

Populasi penelitian ini adalah 162 santri Pondok Pesantren Assalafi, Al Fithrah, Surabaya yang berusia antara 15-18 tahun dan merupakan santri mukim (belajar dan tinggal di Ponpes. Berdasarkan jumlah populasi yang diperoleh, peneliti mengambil sampel penelitian sebanyak 81 santri tanpa memperhatikan jenis kelamin dengan teknik pengambilan sampel random sampling. Teknik sampel random dilakukan dengan jalan memberi kemungkinan yang sama bagi individu yang menjadi anggota sampel penelitian (Winarsunu, 2007). Dari 81 santri yang dijadikan sampel penelitian, hanya 77 santri yang hadir. Hal ini dikarenakan banyak santri yang belum kembali ke Ponpes.

\section{Teknik Pengumpulan Data}

Pengumpulan data yang digunakan dalam penelitian ini dilakukan untuk tiga variabel, yakni kuesioner religiusitas, stres, 
dan psychological wellbeing. Kuesioner dalam penelitian ini digunakan untuk mengetahui hubungan religiusitas dan stres dengan psychological well being pada remaja pondok pesantren. Skala yang digunakan untuk ketiga variabel dalam penelitian ini dinyatakan dalam bentuk skala Likert dalam rentang penilaian 1-4 (mulai dari Sangat Tidak Sesuai/STS hingga Sangat Sesuai/SS). Jenis validitas tes yang digunakan dalam penelitian ini adalah validitas isi (content validity) dan validitas butir. Validitas isi tes ditentukan dengan menggunakan pendapat profesional (professional judgement) dalam proses telaah soal (Suryabrata, 2005). Setelah dilakukan rater kepada professional judgement dan itemitem diperbaiki, kemudian dilakukan uji coba (try out) alat ukur kepada sampel prapenelitian. Sehingga, pada akhirnya diperoleh item yang dianggap layak (valid) untuk diikutsertakan dalam penelitian yang sebenarnya dengan menggunakan bantuan program SPSS 17.0 Statistic for Windows. Dari hasil penghitungan tersebut kemudian dihasilkan koefisien korelasi item total, sehingga dapat dilakukan pemilihan item.

Hasil uji validitas Skala religiusitas dengan menggunakan $r_{\text {hitung }} \geq 0,25$ dan mengalami 3 kali putaran try out menunjukkan bahwa dari 72 item yang telah disediakan, 53 item dinyatakan valid karena memiliki koefisien $\geq 0,25$ dan 19 item gugur karena koefisiennya $\leq 0,25$. Hasil uji validitas kala tingkat stres dengan menggunakan $r_{\text {hitung }} \geq$ 0,25 dan mengalami 2 kali putaran try out menunjukkan bahwa dari 56 item yang telah disediakan, 29 item dinyatakan valid karena memiliki koefisien $\geq 0,25$ dan 23 item gugur karena koefisiennya $\leq 0,25$. Hasil uji validitas skala psychological wellbeing menggunakan $r_{\text {hitung }} \geq 0,25$ dan mengalami 2 kali putaran try out menunjukkan bahwa dari 54 item yang telah disediakan, 38 item dinyatakan valid karena memiliki koefisien $\geq 0,25$ dan 16 item gugur karena koefisiennya $\leq 0,25$.

Pengujian reliabilitas pada penelitan ini menggunakan koefisien Alpha atau Cronbach's Alpha yang dihitung dengan menggunakan program SPSS 17.0 Statistic for Windows. Hasil uji reliabilitas skala religiusitas adalah 0,918, tingkat stress 0,889 , dan psychological wellbeing 0,933 . Koefisien reliabilitasnya $\left(\mathrm{r}_{\mathrm{xx}}\right)$ ketiga skala penelitian ini mendekati angka 1,00; sehingga dapat dikatakan memiliki relibilitas yang cukup tinggi.

\section{Teknis Analisis Data}

Data dianalisis menggunakan analisis regresi berganda dengan bantuan SPSS 17.0 Statistic for Windows. Teknik analisis data regresi linier berganda merupakan suatu teknik statistik parametrik yang digunakan untuk menguji pertautan dua variabel bebas $\left(\mathrm{X}_{1}\right.$ dan $\left.\mathrm{X}_{2}\right)$ dengan variabel terikatnya $(\mathrm{Y})$ (Winarsunu, 2007).

\section{HASIL DAN PEMBAHASAN}

\section{Hasil}

Selain melakukan uji asumsi, peneliti mencari nilai rata-rata (mean), nilai minimun, nilai maksimum, dan standar deviasi dari data yang telah diperoleh. Hasil olahan deskripsi data statistik ialah pada tabel 4.3 di bawah sebagai berikut.

Tabel 4.3 Deskripsi Data Statistik

\begin{tabular}{|l|c|c|c|c|c|}
\hline \multicolumn{7}{|c|}{ Descriptive Statistics } \\
\hline & N & Mean & Std. Deviation & Minimum & Maximum \\
\hline Religiusitas & 77 & 146.68 & 12.428 & 112 & 178 \\
Stres & 77 & 67.00 & 7.527 & 48 & 86 \\
PWB & 77 & 112.90 & 10.223 & 90 & 136 \\
\hline
\end{tabular}


Sampel dalam penelitian ini melibatkan 77 santri Ponpes Assalafi Al-Fithrah, Surabaya. Berdasarkan data statistik tersebut, diketahui bahwa rata-rata untuk variabel religiusitas ialah sebesar 146,68 dengan nilai tertinggi ialah sebesar 178 dan terendah sebesar 112. Sedangkan nilai rata-rata untuk variabel stres ialah sebesar 67,00 dengan nilai tertinggi sebesar 86 dan terendah sebesar 48 . Sementara, variabel psychological well being memiliki rata-rata sebesar 112,90 dengan nilai tertinggi sebesar 136 dan terendah 90. Standar deviasi untuk variabel religiusitas ialah sebesar 12,428; variabel stres sebesar 7,527; dan variabel psychological well being sebesar 10,223.

Peneliti mengelompokkan skor subyek ke dalam dua ketegori, yakni kategori rendah dan kategori tinggi. Pengkategorian ini didasarkan atas tabel 4.3 mengenai deskripsi data statistik. Pembagian kelompok didasarkan atas skor rata-rata norma kelompok, yakni subyek dikatakan memiliki skor rendah apabila skornya dibawah rata-rata dan dinyatakan memiliki skor tinggi apabila memiliki skor di atas rata-rata.

Variabel religiusitas memiliki rata-rata skor sebesar 146,68; sehingga subyek yang memiliki skor total diatas 146,68 dianggap memiliki skor tinggi (kategori tingkat religiusitas yang tinggi) dan dibawah subyek yang memiliki skor total dibawah 146,68 dianggap memiliki skor rendah (kategori tingkat religiusitas yang rendah). Sebaran data subyek berdasarkan norma kelompok, ialah sebagai berikut:

Tabel 4.4 Kategorisasi Data Religiusitas

\begin{tabular}{|c|c|c|}
\hline Kategori & Jumlah & Persentase (\%) \\
\hline Tinggi & 31 & 40,26 \\
\hline Rendah & 46 & 59,74 \\
\hline Jumlah & $\mathbf{7 7}$ & $\mathbf{1 0 0}$ \\
\hline
\end{tabular}

Berdasarkan tabel tersebut, diketahui bahwa dari 77 santri yang menjadi sampel penelitian, diketahui bahwa sebanyak 31 santri atau sebesar 40,26\% santri tergolong dalam kategori tingkat religiusitas yang tinggi dan sebanyak 46 santri atau sebesar 59,74\% santri tergolong dalam kategori tingkat religiusitas yang rendah.

Pengelompokkan subyek berdasarkan tinggi-rendahnya skor yang dicapai diberlakukan juga pada variabel stres dan psychological well being. Variabel stres memiliki rata-rata skor sebesar 67,00 ; sehingga subyek yang memiliki skor total diatas 67,00 dianggap memiliki skor tinggi (kategori tingkat stres yang tinggi) dan subyek yang memiliki skor total dibawah 67,00 dianggap memiliki skor rendah (kategori tingkat stres yang rendah). Adapun sebaran data untuk tingkat stres ialah sebagai berikut:

Tabel 4.5 Kategorisasi Data Stres

\begin{tabular}{|c|c|c|}
\hline Kategori & Jumlah & Persentase (\%) \\
\hline Tinggi & 36 & 46,75 \\
\hline Rendah & 41 & 53,25 \\
\hline Jumlah & $\mathbf{7 7}$ & $\mathbf{1 0 0}$ \\
\hline
\end{tabular}

Berdasarkan tabel tersebut, diketahui bahwa dari 77 santri yang menjadi sampel penelitian, diketahui bahwa sebanyak 36 santri atau sebesar $46,75 \%$ santri termasuk dalam kategori tingkat stres yang tinggi dan sebanyak 41 santri atau sebesar $53,25 \%$ santri termasuk kategori tingkat stres yang rendah.

Variabel psychological well being memiliki rata-rata skor sebesar 112,90; sehingga subyek yang memiliki skor total diatas 112,90 dianggap memiliki skor tinggi (kategori tingkat psychological well being yang tinggi) dan subyek yang memiliki skor total dibawah 112,90 dianggap memiliki skor rendah (kategori tingkat psychological well being yang rendah). Adapun sebaran data untuk tingkat psychological well being ialah sebagai berikut:

Tabel 4.6 Kategorisasi Data Psychological Well Being

\begin{tabular}{|c|c|c|}
\hline Kategori & Jumlah & Persentase (\%) \\
\hline Tinggi & 36 & 46,75 \\
\hline Rendah & 41 & 53,25 \\
\hline Jumlah & $\mathbf{7 7}$ & $\mathbf{1 0 0}$ \\
\hline
\end{tabular}

Berdasarkan tabel tersebut, diketahui 
bahwa dari 77 santri yang menjadi sampel penelitian, diketahui bahwa sebanyak 36 santri atau sebesar $46,75 \%$ santri tergolong kategori tingkat psychological well being yang tinggi dan sebanyak 41 santri atau sebesar 53,25\% santri tergolong dalam ketegori tingkat psychological well being yang rendah.

Uji asumsi normalitas, linearitas, homogenitas, multikolinieritas dan autokorelasi juga dilakukan. Berdasarkan hasil uji normalitas menggunakan kolmogorov-smirnov diketahui bahwa nilai $\mathrm{p}$ atau signifikansi variabel religiusitas sebesar 0,069; stres sebesar 0,067; dan psychological well being sebesar 0,349. Sehingga, dapat dikatakan bahwa distribusi data variabel religiusitas, stres, dan psychological well being termasuk data normal karena memiliki nilai $p$ atau signifikansi $>0,05$.

Hasil uji linieritas ketiga variabel menunjukkan bahwa nilai signifikansi antara variabel religiusitas dan psychological well being ialah sebesar 0,097. Sedangkan nilai multikolinieritas atau tidak terjadi multikolinieritas. Sehingga, diketahui bahwa antara variabel religiusitas dan stres tidak memiliki hubungan antara satu sama lain. Adapun hasil uji autokorelasi menunjukkan bahwa nilai Durbin-Watson sebesar 2,014. Artinya, data variabel religiusitas dan stres bersifat tidak autokolerasi atau tidak terjadi autokolerasi.

Uji analisis data dilakukan setelah seluruh uji asumsi dilakukan dan dianggap memenuhi uji keparametrikan. Berdasarkan hasil uji asumsi, diketahui bahwa data variabel religiusitas, stres, dan psychological well being merupakan data normal, linier, homogen, tidak multikolinieritas, dan tidak terjadi autokolerasi. Setelah asumsi terpenuhi, tahap selanjutnya ialah melakukan analisis regresi berganda.

Berdasarkan hasil pengolahan data dengan analisis regresi berganda dengan bantuan program SPSS 17. statistic for windows diperoleh informasi sebagai berikut:

Tabel 4.15 Ringkasan Hasil Uji Analisis Regresi Linier Berganda

\begin{tabular}{|l|c|c|c|c|c|}
\hline $\begin{array}{c}\text { Hubungan antar } \\
\text { variabel }\end{array}$ & $\mathbf{R}$ & $\mathbf{R}_{\text {Square }}$ & $\begin{array}{c}\text { Adjusted } \\
\text { R Square }\end{array}$ & F & Signifikansi \\
\hline $\begin{array}{l}\text { religiusitas dan stres } \\
\text { dengan psychological } \\
\text { well being }\end{array}$ & $0,770^{\mathrm{a}}$ & 0,593 & 0,582 & 53,835 & $0,000^{\mathrm{a}}$ \\
\hline
\end{tabular}

signifikansi antara variabel stres dan psychological well being ialah sebesar 0,335. Sehingga dapat dikatakan bahwa distribusi data religiusitas, stres, dan psychological well being termasuk data linier karena memiliki nilai $p$ atau signifikansi $>0,05$. Hasil uji homogenitas menunjukkan bahwa nilai signifikansi variabel religiusitas ialah sebesar 0,885 . Sedangkan nilai signifikansi variabel stres ialah sebesar 0,078. Sehingga, dapat dikatakan bahwa variansi nilai yang diperbandingkan termasuk data homogen karena memiliki nilai $\mathrm{p}$ atau signifikansi $>0,05$.

Hasil Uji Multikolinieritas menunjukkan nilai VIF sebesar 1,001. Artinya, data variabel religiusitas dan stres bersifat tidak
Nilai $\mathrm{R}_{\text {Square }}$ sebesar 0,593 menunjukkan bahwa sumbangan atau kontribusi yang diberikan variabel religiusitas dan stres kepada psychological well being ialah sebesar 0,593 . Artinya, sebesar $59,3 \%$ variasi pada psychological well being dipengaruhi oleh variabel religiusitas dan stres dan sisanya sebesar $40,7 \%$ disebabkan oleh variabel lain yang tidak diukur oleh peneliti.

Berdasarkan tabel tersebut, diketahui bahwa nilai probabilitas $\mathrm{F}$ (F-hitung) dalam regresi berganda sebesar 53,835. P-value = 0,000 lebih kecil dari 0,05 menjelaskan bahwa terdapat hubungan yang signifikan antara variabel dependen dengan variabel independen. Dengan demikian Ha yang 
menyatakan terdapat hubungan antara religiusitas dan stres dengan psychological well being diterima. Artinya, variabel religiusitas dan stres secara bersama-sama memiliki hubungan dengan variabel psychological well being. mengalami penurunan sebesar $55,9 \%$.

Hubungan antara stres dan psychological well being memiliki nilai koefisien regresi sebesar $-0,460$. Tanda minus menyatakan arah hubungan yang tidak searah, dimana kenaikan variabel bebas (X)

Tabel 4.16 Hubungan antara Religiusitas dan Stres dengan Psychological Well Being

\begin{tabular}{|c|c|c|c|c|c|}
\hline \multirow{2}{*}{ Model } & \multicolumn{6}{|c|}{$\begin{array}{c}\text { Coefficients } \\
\text { Unstandardized } \\
\text { Coefficients }\end{array}$} & $\begin{array}{c}\text { Standardized } \\
\text { Coefficients }\end{array}$ & \multirow{2}{*}{ t } & Sig. \\
\cline { 2 - 4 } & $\mathrm{B}$ & Std. Error & Beta & & \\
\hline (Constant) & 61.750 & 11.429 & & 5.403 & .000 \\
Religiusitas & .559 & .061 & .680 & 9.154 & .000 \\
Stres & .460 & .101 & .339 & .566 & .000 \\
\hline
\end{tabular}

a . Dependent Variable: PWB

Berdasarkan hasil uji-t pada tabel tersebut, diketahui bahwa nilai signifikansi variabel religiusitas sebesar $0,000(<0,05)$ menunjukkan bahwa religiusitas memiliki hubungan yang signifikan dengan psychological well being. Dengan demikian hipotesis alternatif $\left(\mathrm{Ha}_{1}\right)$ yang diajukan diterima. Artinya, religiusitas berhubungan dengan psychological well being. Dan nilai signifikansi variabel stres sebesar 0,000 (< $0,05)$ menunjukkan bahwa stres memiliki hubungan yang signifikan dengan psychological well being. Dengan demikian hipotesis alternatif $\left(\mathrm{Ha}_{2}\right)$ yang diajukan diterima. Artinya, stres berhubungan dengan psychological well being.

Hubungan antara religiusitas dan psychological well being bersifat positif, yang dapat dilihat dari nilai koefisien regresi sebesar 0,559 ; tanda positif menyatakan arah hubungan yang searah, dimana kenaikan atau penurunan variabel bebas (X) akan mengakibatkan kenaikan/ penurunan variabel terikat $(\mathrm{Y})$ (Riduwan, dkk, 2011). Artinya, apabila religiusitas naik satu tingkatan maka psychological well being diprediksikan mengalami kenaikan sebesar 55,9\%. Begitu pula sebaliknya, jika religiusitas turun satu tingkatan maka psychological well being diprediksikan mengakibatkan penurunan variabel terikat (Y), begitu pula sebaliknya. Sehingga, jika stres turun satu tingkatan maka psychological well being diprediksikan mengalami kenaikan sebesar $46 \%$. Begitu pula sebaliknya, apabila stres naik satu tingkatan maka psychological well being mengalami penurunan sebesar $46 \%$.

\section{Pembahasan}

Penelitian ini bertujuan untuk mengetahui hubungan antara religiusitas dan stres dengan psychological well being pada remaja Pondok Pesantren Assalafi Al-Fithrah, Surabaya. Berdasarkan uji analisis data yang telah dilakukan dengan menggunakan uji-t dalam teknik analisis regresi linier berganda diketahui bahwa psychological well being berhubungan secara signifikan dan positif dengan religiusitas yang dapat dilihat dari nilai $\mathrm{p}$ signifikansi sebesar $0,000(<0,05)$. Arah hubungan bersifat positif dengan koefisien regresi sebesar 0,559. Sehingga, hipotesis pertama yang menyatakan "terdapat hubungan antara religiusitas dengan psychological well being", diterima. Sedangkan, hipotesis yang menyatakan "tidak terdapat hubungan antara religiusitas dengan psychological well being", ditolak. 
Hubungan antara religiusitas dengan psychological well being yang bernilai 0,559 menunjukkan arah hubungan yang positif, artinya sebesar $55,9 \%$ dari variasi psychological well being dapat diprediksikan melalui religiusitas. Arah hubungan positif berarti bahwa semakin tinggi religiusitas individu maka semakin tinggi pula psychological well being-nya. Begitu pula sebaliknya, semakin rendah religiusitas maka semakin rendah pula psychological well being. Pernyataan tersebut sesuai dengan penelitian yang dilakukan oleh Koening, Kvale, dan Ferrel (dalam Papalia et. al., 2002) yang menunjukkan bahwa individu yang tingkat religiusnya tinggi mempunyai sikap yang lebih baik, lebih merasa puas dalam hidup, dan hanya sedikit mengalami rasa kesepian.

Penelitian lain yang juga mendukung ialah penelitian Coke (1992); Walls \& Zarit (1991) yang menunjukkan bahwa individu yang merasa mendapatkan dukungan dari tempat peribadatan mereka cenderung mempunyai tingkat psychological well being yang tinggi. Sehingga, para ahli menyimpulkan bahwa religiusitas mempunyai hubungan yang kuat dengan psychological well being (Papalia et. al., 2002).

Senada dengan Spranger (dalam Dister, 1994) yang menyatakan bahwa individu yang memiliki nilai religius menempatkan kesatuan sebagai nilai tertinggi dalam hidupnya. Individu-individu semacam ini hidupnya dikuasai oleh keseluruhan nilai yang memuncak dalam nilai tertinggi, yaitu nilai Tuhan. Nilai-nilai religius mampu memberikan suatu kerangka yang menjadi acuan bagi individu dalam berfikir, memandang diri, dan kehidupannya. Individu yang telah mencapai psychological well being yang baik tampak dalam bagaimana ia mampu menerima segala kondisi yang ada pada dirinya, baik masa lalu, saat ini, dan masa depannya, serta selalu berserah kepada Yang Mahatinggi.
Hurlock (1990) menyatakankan bahwa minat remaja pada agama disebabkan karena remaja mulai menganggap bahwa agama berperan penting bagi kehidupan. Minat terhadap agama yang meningkat pada masa remaja, antara lain tampak pada keinginan remaja untuk membahas masalah agama, mengikuti pelajaran-pelajaran agama di sekolah, mengikuti berbagai ritual keagamaan.

Remaja lebih memiliki ketertarikan pada agama dan keyakinan spiritual dibanding aak-anak. Pada masa anak-anak, mereka mengandalkan sepenuhnya pada keyakinan orang tua. Pada masa remaja akhir, individu menghadapi keputusan-keputusan pribadi, mulai mengevaluasi beberapa pertanyaan mengenai keyakinan dan kepentingan orang lain (Santrock, 2003).

Piaget (dalam Hurlock, 1990) menyatakan bahwa remaja merupakan masa yang telah mencapai kematangan secara emosi, sosial, dan fisik. Perubahan dan kematangan yang dialami individu pada masa remaja membuat mereka harus bisa menyesuaikan diri dan mental dalam pembentukan sikap, nilai, dan minat baru. Pada masa remaja, salah satu minat yang berubah ialah minatnya terhadap agama. Remaja mulai kritis terhadap ajaran agama yang dianutnya. Remaja juga mulai menghayati setiap hal yang terjadi dalam lingkungannya. Kehidupan yang religius cenderung mendorong remaja untuk lebih dekat ke arah hidup yang religius (Jalluddin, 2002).

Colbert, dkk (2009) menyebutkan bahwa usia berkorelasi positif dengan orientasi keagamaan dan usia berhubungan dengan religiusitas secara signifikan, yakni keterlibatan keagamaan yang lebih tinggi dihubungkan dengan kematangan dan usia. Agama melibatkan aktivitas keagamaan cenderung meningkat dengan usia. Semakin bertambahnya usia seseorang maka semakin ia mengetahui kondisi terbaik bagi dirinya. Oleh karena itu, individu tersebut mampu mengatur lingkungannya sesuai dengan keadaan dirinya (Ryff, 1989). Meskipun 
dalam penelitian ini tidak melibatkan faktor usia untuk membedakan religiusitas, namun usia remaja yang menjadi karakteristik dalam penelitian dinilai sebagai usia yang matang.

Oleh karena penelitian dilakukan di pondok pesantren, sehingga relevan apabila dikatakan remaja pondok pesantren memiliki minat yang lebih terhadap agama. Minat tersebut sudah tampak dari keputusan yang mereka ambil untuk masuk dan terdaftar sebagai santri pondok pesantren. Remaja yang telah mengambil keputusan untuk menjadi santri pondok pesantren berarti telah mengetahui akan segala konsekuensi yang akan dihadapi selama belajar dan tinggal di pondok pesantren. Remaja yang mampu mengambil keputusan dalam hidupnya dinilai memiliki psychological well being yang baik. Karena sesuai dengan beberapa aspek yang ada dalam psychological well being, yakni kemandirian, penguasaan lingkungan, tujuan hidup, dan pertumbuhan pribadi.

Hal tersebut didukung penelitian Rathi dan Rastogi (2007) yang menyatakan bahwa remaja yang menunjukkan kekuatan dalam tiap-tiap maupun semua aspek yang ada akan berada dalam psychological well being yang baik, sementara remaja yang berjuang dalam area ini akan berada dalam psychological well-being yang rendah.

Romeo et. al.(dalam Taylor, 2009) menyatakan bahwa religion dapat menunjang psychological well being. Individu dengan keyakinan spiritual yang kuat dilaporkan memiliki kepuasan hidup yang besar, kebahagiaan personal yang besar, dan sangat kecil dalam konsekuensi negatif atas peristiwa hidup yang traumatis dibandingkan dengan individu yang tidak spiritual.

Hipotesis kedua yang menyatakan "terdapat hubungan antara stres dengan psychological well being', juga diterima. Berdasarkan uji analisis data yang telah dilakukan dengan menggunakan uji-t dalam teknik analisis regresi linier berganda diketahui bahwa psychological well being berhubungan secara signifikan dengan variabel stres, tetapi hubungan tersebut bersifat negatif. Hal tersebut dapat dilihat dari nilai p signifikansi sebesar $0,000(<0,05)$ dan koefisien regresi sebesar $-0,460$.

Hubungan antara stres dengan psychological well being yang bernilai $-0,460$ menunjukkan bahwa arah hubungan negatif, artinya sebesar $46 \%$ dari variasi psychological well being dapat diprediksikan melalui variabel stres. Arah hubungan yang negatif berarti bahwa semakin tinggi stres remaja maka semakin rendah psychological well being-nya. Begitu pula sebaliknya, semakin rendah stres maka semakin tinggi psychological well being. Hal ini didukung oleh penelitian yang dilakukan Malek, dkk (2010). Dalam penelitiannya diketahui bahwa terdapat hubungan yang negatif yang signifikan antara sumber stres dengan psychological well being. Hubungan tersebut dipengaruhi oleh coping behaviour sebagai variabel moderator. Penelitian tersebut menguatkan hasil penelitian yang menyebutkan bahwa semakin rendah stres yang dialami oleh remaja maka akan mampu meningkatkan psychological well being.

Remaja dengan psychological well being yang baik akan mampu memilih coping yang tepat bagi dirinya dan mampu berfikir positif. Penyebab munculnya stres pada remaja mengalami peningkatan dibanding masa-masa sebelumnya. Sehingga, dapat dikatakan bahwa banyak faktor yang dapat menghasilkan stres dalam kehidupan remaja. Faktor-faktor tersebut dapat bersifat ekstern atau hanya berupa kehidupan sehari-hari (Santrock, 2003).

Setiap periode kehidupan memiliki stres atau ketegangan sendiri. Saat remaja, mereka harus menghadapi perkembangan identitas, perasaan tidak aman (feeling of insecurity), perubahan suasana hati ( $m o o d$ swings), dan tekanan teman sebaya, tetapi mayoritas mengembangkan persepsi yang positif tentang diri mereka sendiri, perasaan mampu (feeling of competence) akan ketrampilan mereka, relasi yang positif dengan teman- 
teman dan keluarga, dan pandangan yang optimistik terhadap masa depan mereka (Myers, dalam Santrock, 2002a).

Walker (dalam Nasution, 2007) dalam penelitiannya pada 60 orang remaja diketahui bahwa penyebab utama ketegangan dan masalah yang ada pada remaja berasal dari hubungan dengan teman dan keluarga, tekanan dan harapan dari diri mereka sendiri dan orang lain, tekanan di sekolah oleh guru dan pekerjaan rumah, tekanan ekonomi dan tragedi yang ada dalam kehidupan mereka.

Lazarus (dalam Taylor, 2009) memberikan penjelasan mengenai pengertian stres. Stres merupakan kemampuan individu menilai suatu peristiwa sebagai situasi yang bersifat positif, negatif, atau netral. Lazarus menegaskan bahwa seseorang dapat menjadi sangat stres dibanding orang lain apabila orang tersebut menilai peristiwa yang dialaminya sebagai stressor dan ia dapat berpeluang mengalami stres yang lebih berat.

Lazarus (dalam Santrock, 2003) membagi penilaian individu terhadap suatu peristiwa menjadi dua bagian, yakni penilaian primer dan penilaian sekunder. Pada penilaian primer, individu menentukan apakah peristiwa yang dialaminya dimaknai sebagai suatu peristiwa yang bersifat positif, negatif, atau netral. Kemudian muncul penilaian sekunder yang menunjukkan kemampuan individu dalam melakukan coping dan apakah ia cukup mampu menghadapi bahaya, ancaman, dan tantangan dalam peristiwa yang terjadi.

Stress adalah suatu kondisi ketegangan yang mempengaruhi emosi, proses berpikir dan kondisi seseorang (Handoko, dalam jurnal-sdm.blogspot.com). Stress yang terlalu besar dapat mengancam kemampuan seseorang untuk menghadapi lingkungannya. Stres pada remaja Ponpes dapat disebabkan oleh tuntutan-tuntutan diluar dirinya, seperti batas minimum yang harus dicapainya pada materi agama, yang terkadang membuat mereka merasa tidak mampu untuk mencapai target tersebut.
Bagi remaja yang tinggal di Ponpes wajib bagi mereka untuk mendalami dan menguasai hal-hal yang berkaitan dengan ajaran agama Islam. Hal ini terkadang membuat remaja Ponpes merasa tertekan dengan tuntutan yang diberikan kepada mereka. Di satu sisi, mereka berusaha untuk mematuhi aturan yang diterapkan pihak Ponpes. Namun di sisi lain, mereka merasa memiliki kemampuan yang terbatas yang membuat mereka merasa tidak mampu memenuhi target yang ditetapkan pihak pesantren. Kondisi tersebut membuat mereka merasa tertekan yang pada akhirnya dapat memunculkan stres. Stres ini juga dapat muncul karena para santri beranggapan bahwa lingkungan yang ada tidak sesuai dengan yang dirasakannya. Selain masalahmasalah internal dalam Ponpes, para santri juga memiliki permasalahan yang berasal dari luar lingkungan Ponpes, seperti misalnya permasalahan ekonomi keluarga.

Menurut Lazarus (dalam Taylor, 2009), terdapat dua strategi yang dapat digunakan dalam melakukan coping, yakni problemfocus coping dan emotion-focus coping. Problem-focus coping ialah usaha mengatasi stres dengan cara mengatur atau mengubah masalah yang dihadapi dan lingkungan sekitarnya yang menyebabkan terjadinya tekanan. Emotion-focus coping merupakan usaha mengatasi stres dengan cara mengatur respon emosional dalam rangka menyesuaikan diri dengan dampak yang akan ditimbulkan oleh suatu kondisi atau situasi yang dianggap penuh tekanan.

Pada masa anak-anak, kebanyakan bentuk coping yang digunakan adalah problem-focus coping. Namun, ketika remaja yang digunakan ialah emotion-focus coping. Individu cenderung untuk menggunakan problem-focus coping dalam menghadapi masalah-masalah yang menurut individu tersebut dapat dikontrolnya. Sebaliknya, individu cenderung menggunakan emotionfocus coping dalam menghadapi masalahmasalah yang menurutnya sulit untuk 
dikontrol (Lazarus \& Folkman, dalam Taylor, 2009 ). Terkadang individu dapat menggunakan kedua strategi tersebut secara bersamaan, namun tidak semua strategi coping pasti digunakan oleh individu (Taylor, 2009).

Ryff (1989) menyatakan bahwa kesejahteraan jiwa seseorang tidak hanya dinilai dari terbebasnya ia dari tekanan atau masalah mental lain. Salah satu kriteria yang harus dimiliki individu dengan psychological well being yang baik ialah individu yang mampu menilai dirinya secara positif. Dengan penilaian yang positif terhadap diri, individu tersebut mampu menilai segala peristiwa hidup yang terjadi pada dirinya sebagai sesuatu yang sifatnya positif atau netral. Apabila ia menilai suatu peristiwa sebagai hal yang negatif atau sebagai stressor, maka akan berpeluang mengalami stres yang lebih berat.

Hipotesis ketiga yang menyatakan "terdapat hubungan antara religiusitas dan stres dengan psychological well being", diterima. Ini terlihat dari nilai signifikansi sebesar $0,000(<0,05)$ yang berarti bahwa terdapat hubungan yang signifikan antara variabel dependen dengan variabel independen. Artinya, variabel religiusitas dan stres secara bersama-sama memiliki hubungan dengan variabel psychological well being. Masing-masing variabel independen $\left(\mathrm{X}_{1}\right.$ dan $\left.\mathrm{X}_{2}\right)$ memiliki kontribusi dan arah hubungan yang berbeda. Hubungan antara religiusitas dan psychological well being memiliki arah yang positif dengan kontribusi sebesar 55,9\%. Hal ini berarti semakin tinggi religiusitas remaja, maka semakin tinggi pula psychological well beingnya. Begitu pula sebaliknya, semakin rendah religiusitas, maka semakin rendah psychological well being yang dicapai. Sedangkan, hubungan antara stres dan psychological well being berarah negatif dengan kontribusi sebesar $46 \%$. Hal ini berarti semakin tinggi stres, maka semakin rendah psychological well being yang dicapai. Begitu pula sebaliknya, semakin rendah stres yang dialami remaja, maka semakin tinggi psychological well being yang dicapai.

Pada pengolahan data, diketahui nilai $\mathrm{R}_{\text {square }}$ sebesar 0,593 . Nilai tersebut menunjukkan bahwa sumbangan atau kontribusi yang diberikan variabel religiusitas dan stres kepada psychological well being ialah sebesar 0,593. Artinya, sebesar 59,3\% variasi pada psychological well being dipengaruhi oleh variabel religiusitas dan stres dan sisanya sebesar $40,7 \%$ disebabkan oleh variabel lain yang tidak diukur oleh peneliti.

Hal tersebut didukung oleh penelitin Lee (2007) yang menyatakan bahwa terdapat signifikansi antara stres dengan coping religiusitas/spiritualitas dalam hubungan antara stres dan depresi. Hubungan antara stres dan psychological well being diprediksikan berhubungan langsung, dengan level yang tinggi pada stres berhubungan dengan rendahnya well being (yakni simptom terbesar dari depresi). Dalam penelitian ini juga dijelaskan bahwa coping religius dapat mengurangi penyebab dari stres terhadap depresi dan ditemukan bahwa coping religius berhubungan dengan persepsi dari stres dan psychological well being.

Dalam penelitian Lee (2007) ditemukan bahwa coping religiusitas/ spiritualitas merupakan faktor moderator pada hubungan antara persepsi terhadap stres dan pschological well being. Hasilnya menunjukkan bahwa nilai tinggi pada religiusitas berhubungan dengan nilai yang rendah dari psychological distress symptomps.

Munculnya psychological well being dapat terganggu oleh adanya stres yang dihadapi individu. Menurut Ryff dan Singer (dalam Nugraeni, 2009) salah satu aspek dalam psychological well being dapat lebih tinggi pada kelompok individu berpendidikan tinggi dibanding kelompok berpendidikan rendah. Pendidikan memberikan ketahanan dalam menghadapi stres, tantangan, dan kesulitan hidup. Sebaliknya, kurangnya pendidikan dapat mengganggu munculnya psychological well being. 
Ryff \& Singer (dalam Papalia et. al., 2002) menegaskan bahwa tingkat well being dapat lebih tinggi pada pria dan wanita yang berpendidikan dan memiliki pekerjaan yang baik. Faktor demografis lain yang dapat mempengaruhi psychological well being adalah perbedaan jenis kelamin, usia, dan budaya. Perbedaan jenis kelamin tidak menunjukkan perbedaan yang signifikan dalam mencapai kebahagiaan (happiness). Perbedaan tersebut hanya tampak pada salah satu aspek psychological well being saja, yakni mengenai hubungan positif dengan orang lain.

Pada faktor usia, diketahui bahwa dengan bertambahnya usia seseorang maka ia semakin mengetahui kondisi yang terbaik bagi dirinya. Aspek lain yang ikut meningkat seiring bertambahnya usia ialah aspek kemandirian. Peningkatan tersebut khususnya terjadi antara remaja muda dan tengah baya (Ryff, 1989). Dengan demikian, kemandirian dapat diasumsikan tidak penting bagi remaja untuk beradaptasi dengan lingkungan secara psikologis (Garcia \& Siddiqui, 2009). Namun, faktor demografis ini tidak terlalu signifikan dalam menentukan kesejahteraan psikologis (Ryff, 1989).

Faktor lain selain faktor demografis yang dapat mempengaruhi munculnya psychological well being adalah dukungan sosial yang diterima remaja. Adanya dukungan sosial dapat membantu remaja dalam mengembangkan dirinya ke arah yang lebih positif dan memberikan support pada individu dalam menghadapi permasalahan sehari-hari (Ryff, dalam Nugraeni, 2009).

Taylor (2009) menyatakan bahwa social support adalah sumber proteksi psikososial terpenting. Perlindungan sekitar dan hubungan pertemanan telah lama dianggap sebagai aspek kehidupan yang sangat memuaskan secara emosional. Juga, dapat menghentikan secara sementara pengaruh stres, dapat membantu seseorang untuk mengatasi masa-masa sulit, dan mengurangi kemungkinan stres, yang menjerumuskan seseorang pada kehidupan yang tidak sehat.

Faktor religiusitas dan kepribadian juga memiliki andil dalam menetukan psychological well being seseorang. Papalia et. al. (2002) religiusitas memiliki hubungan yang kuat dengan psychological well being. Penelitian Koening, Kvale, dan Ferrel (dalam Papalia et. al., 2002) menunjukkan bahwa individu yang tingkat religiusnya tinggi mempunyai sikap yang lebih baik, lebih merasa puas dalam hidup, dan hanya sedikit mengalami rasa kesepian.

Hasil penelitian Schmutte dan Ryff (dalam Nugraeni, 2009) menunjukkan bahwa individu yang termasuk dalam kategori extraversion, conscientiousness, dan low neuroticism mempunyai skor tinggi pada dimensi penerimaan diri, penguasaan lingkungan, dan keterarahan hidup. Individu yang termasuk dalam kategori openness to experience mempunyai skor tinggi pada dimensi pertumbuhan pribadi; individu yang termasuk kategori agreeableness dan extraversion mempunyai skor tinggi pada dimensi hubungan positif dengan orang lain dan individu yang termasuk kategori low neuroticism mempunyai skor tinggi pada dimensi otonomi.

Cloninger (2004) menyatakan bahwa kesadaran diri dalam penerimaan diri merupakan langkah penting untuk menjadi bahagia. Oleh karena itu, apabila seseorang ingin dapat menyesuaikan diri, merasa baik, dan mampu menyelesaikan masalah hidupnya, orang tersebut harus menerima semua bagian yang berbeda dalam dirinya (Garcia \& Siddiqui, 2009). Dengan demikian dapat dikatakan bahwa penerimaan diri yang baik akan dapat menjadikan individu mampu menghadapi permasalahan yang ada dalam hidupnya. Penerimaan diri yang baik dapat dicapai dengan mendekatkan diri kepada kemanunggalan yang diyakininya untuk dapat meningkatkan religiusitasnya.

Ketiga hipotesis dalam penelitian ini yang menyebutkan bahwa "terdapat hubungan antara religiusitas dan 
psychological well being pada remaja pondok pesantren", "terdapat hubungan antara stres dan psychological well being pada remaja pondok pesantren", dan "terdapat hubungan antara religiusitas dan stres dengan psychological well being pada remaja pondok pesantren", diterima. Berdasarkan hasil analisis, diketahui bahwa sebesar 40,26\% santri pondok pesatren tergolong dalam kategorisasi tingkat religiusitas tinggi dan sebesar $59,74 \%$ santri berada dalam kategorisasi tingkat religiusitas rendah. Untuk stres, sebesar $46,75 \%$ santri termasuk dalam kategori tingkat stres yang tinggi dan sebesar $53,25 \%$ santri termasuk kategori tingkat stres yang rendah. Sedangkan untuk psychological well being diketahui sebesar $46,75 \%$ santri tergolong kategori tingkat psychological well being yang tinggi dan sebesar $53,25 \%$ santri tergolong dalam ketegori tingkat psychological well being yang rendah.

Remaja Ponpes Assalafi Al-Fithrah, Surabaya percaya bahwa setiap permasalahan akan ada jalan keluarnya. Mereka memaknai setiap permasalahan sebagai sesuatu yang positif. Mereka cenderung memilih untuk berdoa'a dan berserah diri pada Allah yang mereka yakini dapat membantu mereka untuk keluar dari permasalahan tersebut. Dalam kaitannya dengan aspek-aspek dalam psychological well being, lingkungan pondok pesantren yang religius ditunjang dengan keyakinan akan kebesaran Allah dapat membantu mereka dalam mencapai psychological well being yang baik. Meskipun pada awal menjadi santri mereka mengalami kesulitan dalam beradaptasi dan bergaul dengan lingkungan baru, namun lambat laun mereka mampu menerima dan berbaur dengan lingkungan tersebut.

Pada penelitan ini diketahui sebesar 59,3\% variasi pada psychological well being dipengaruhi oleh variabel religiusitas dan stres dan sisanya sebesar $40,7 \%$ disebabkan oleh variabel lain yang tidak diukur oleh peneliti. Untuk itu, perlu kiranya dilakukan penelitian lanjutan yang dapat mendukung hasil dari penelitian ini. Selain itu, dapat diketahui variabel lain yang mungkin berpengaruh terhadap munculnya psychological well being pada remaja, khususnya remaja pondok pesantren. Penelitan lebih lanjut dapat dilakukan di tempat lain atau pondok pesantren yang berbeda, sehingga dapat diperoleh hasil penelitian yang lebih baik dari penelitian sebelumnya.

\section{SIMPULAN}

Berdasarkan hasil penelitian yang dilakukan di Pondok Pesantren Assalafi AlFihtrah, Surabaya dapat disimpulkan bahwa religiusitas dan psychological well being memiliki hubungan yang signifikan dengan nilai signifikansi $0,000(<0,05)$. Hubungan antara religiusitas dan psychological well being bersifat positif dengan nilai koefisien regresi sebesar 0,559 . Tanda positif menyatakan arah hubungan yang searah. Artinya, semakin tinggi religiusitas, maka semakin tinggi psychological well being. Begitu pula sebaliknya, semakin rendah religiusitas maka semakin rendah psychological well being. Dan dapat disimpulkan bahwa kontribusi variabel religiusitas pada psychological well being ialah sebesar 55,9\%.

Stres dengan psychological well being memiliki hubungan yang signifikan dengan nilai signifikansi sebesar $0,000(<0,05)$ dengan nilai koefisien regresi sebesar $-0,460$. Tanda minus menyatakan arah hubungan yang tidak searah. Artinya, semakin tinggi stres maka semakin rendah psychological well being. Begitu pula sebaliknya, semakin rendah stres maka semakin tinggi psychological well being. Dan dapat disimpulkan bahwa kontribusi variabel stres pada psychological well being ialah sebesar $46 \%$.

Nilai signifikansi sebesar 0,000 berarti religiusitas dan stres secara bersama-sama memiliki hubungan yang signifikan dengan psychological well being. Dengan sumbangan 
yang diberikan religiusitas dan stres sebesar 0,593 atau 59,3\%; artinya, sebesar 59,3\% variasi pada psychological well being dipengaruhi oleh religiusitas dan stres. Sedangkan sisanya sebesar 40,7\% disebabkan oleh variabel lain yang tidak diukur dalam penelitian ini.

Berdasarkan hasil pengolahan dan kategorisasi data, diketahui bahwa sebesar $40,26 \%$ santri pondok pesatren tergolong dalam kategorisasi tingkat religiusitas tinggi dan sebesar $59,74 \%$ santri berada dalam kategorisasi tingkat religiusitas rendah. Untuk stres, sebesar $46,75 \%$ santri termasuk dalam kategori tingkat stres yang tinggi dan sebesar $53,25 \%$ santri termasuk kategori tingkat stres yang rendah. Sedangkan untuk psychological well being diketahui sebesar $46,75 \%$ santri tergolong kategori tingkat psychological well being yang tinggi dan sebesar 53,25\% santri tergolong dalam ketegori tingkat psychological well being yang rendah

\section{DAFTAR PUSTAKA}

Chaplin, J. P. (2009) . Kamus Lengkap Psikologi. Terjemahan oleh Kartini Kartono. Jakarta: Rajawali Pers.

Colbert, Linda K., dkk. (2009). A Study of Religiosity and Psychological Wellbeing Among African Americans: Implications for Counseling and Psychotherapeutic Processes. Journal Relig Health (Online) Vol. 48 (278289) (http://proquest.umi.com/, diakses 10 Januari 2011).

Dister, N. S. (1994). Pengantar Psikologi Agama: Pengalaman dan Motivasi Beragama (edisi kedua). Jakarta: Kanisius.

Garcia, D.,\& Siddiqui A. (2009). Adolescents' Psychological Well-Being and Memory for Life Events: Influences on Life Satisfaction with Respect to Tempramental Dispositions. Journal Happines Stud. (Online),10 (407-419) (http://proquest.umi.com/, diakses 10 Januari 2011).

Hasan, M. I. (2002). Pokok-pokok Materi Metodologi Penelitian dan Aplikasinya. Bogor: Ghalia Indonesia.

Hurlock, Elizabeth B. (1990). Psikologi Perkembangan Suatu Pendekatan Sepanjang Rentang Kehidupan. Terjemahan oleh Istiwidayanti dan Soedjarwo. Edisi kelima. Jakarta: Erlangga.
Jalaluddin. 2002. Pengantar Psikologi Agama. Edisi revisi. Jakarta: RajaGrafindo Persada.

Lee, Bong-Jae. (2007). Moderating Effects of Religious/ Spritual Coping in the Relation Between Perceived Stress and Psychological Well-Being. Pastoral Psychol (Online), 55:751-759 (http://proquest.umi.com/, diakses 17 Februari 2011).

Malek, M. D., dkk. (2010). Stress and Psychological Well-Being in UK and Malaysian Fire Fighters. Cross Cultural Management: An International Journal (Online) Vol. 17, No. 1, 50-61 (http://proquest.umi.com/, diakses 17 Februari 2011).

Muzammilah. (2008). Tugas Perkembangan Laki-laki Dewasa Awal di Pondok Pesantren Al Hikam Malang. Skripsi (tidak diterbitkan). Surabaya: Fakultas Psikologi Universitas Surabaya.

Nasution, I. K. (2007). Stres pada Remaja. (Online). http://library.usu.ac.id/ download/fk/132316815\%281\%29.pdf . diakses 7 Maret 2011.

Nugraeni, Leny, Kartika. (2009). Hubungan antara Tingkat Stres dan Tingkat Hardiness dengan Psychological Well Being pada Penderita Kanker di Instalasi Rawat Inap RSU Haji Surabaya. Skripsi (tidak diterbitkan). 
Surabaya. Universitas Airlangga.

Papalia, Diane E. (2002). Adult Development and Aging. New York: Mc Graw Hill.

Rathi, N., \& Rastogi, R. (2007). Meaning in Life and Psychological Well Being in Pre-Adolescents and Adolescents. Journal of the Indian Academy of Applied Psychology (Online) Vol. 33, No. 1, 31-38.

http://medind.nic.in/jak/t07/i1/jakt07i1 p31.pdf, diakses 12 Januari 2011.

Riduwan, R. A. (2011). Cara Mudah Belajar SPSS 17.0 dan Aplikasi Statistik Penelitian. Bandung: Alfabeta.

Ryff, C. D. (1989). Happiness is everything, or is it? Explorations on the meaning of psychological wellbeing. Journal of Personality and Social Psychology. (Online) 57, 10691081. http://www.rci. rutgers.edu/ jmohlman/handouts/perso nality/articles personality seminar happiness.pdf, diakses 24 Januari 2011).

Santrock, John W. (2002). Live Span Development: Perkembangan Masa Hidup. Jilid I. Edisi Kelima. Terjemahan Juda Damanik dan Achmad Chusairi. Jakarta: Erlangga.
Santrock, John W. (2003). Adolescence (6th ed.): Perkembangan Remaja. Terjemahan Juda Damanik dan Achmad Chusairi. Jakarta: Erlangga.

Steinberg, L. (2005). Adolescence (sevened). New York: Mc Graw Hill.

Suryabrata, Sumadi. (2005). Pengembangan Alat Ukur Psikologis. Yogyakarta: Andi.

Suryandari, Ita. (2004). Perbedaan Religiusitas Remaja ditinjau dari Coping Behavior. Skripsi (tidak diterbitkan). Surabaya: Fakultas Psikologi Universitas Surabaya.

Taylor, Shelley E. (2009). Health Psychology (7thed). New York: McGraw-Hill.

Winarsunu, T. (2007). Statistik dalam Penelitian Psikologi dan Pendidikan. Malang: Universitas Muhammadiyah Malang. 